\title{
Konsekuensi Consumer Engagement: Iklan dan Konten Media Sosial Berfokus pada Konsumen Restoran Indonesia: Perspektif Uses and Gratification Theory
}

\author{
Juliana ${ }^{1)}$, Amelda Pramezwary ${ }^{2)}$ Alicia $^{3)}$, Daria ${ }^{4)}$, Fenny ${ }^{5)}$, Rhoswenlin ${ }^{6)}$ \\ Pengelolaan Perhotelan, Fakultas Pariwisata, Universitas Pelita Harapan 1,2,3,4,5,6) \\ E-mail : Juliana.stpph@uph.edu
}

\begin{abstract}
Abstrak
Pada masa pandemi covid 19 ini kehadiran social media juga membangun pengaruh iklan dan konten di dalamnya untuk mempengaruhi konsumen restoran favorit di negara Indonesia dalam melakukan pembelian produk maupun jasa dan akan membangun consumer engagement. Sehingga, dalam pemasaran yang dilakukan oleh restoran tersebut pada saat ini juga memiliki dampak yang besar bagi keberlangsungan restoran untuk menarik konsumen yang ada demi menciptakan kestabilan pada restoran serta adanya waktu jangka panjang bagi restoran dalam melakukan ekspansi atau promosi terhadap perkembangannya tersebut. Kehadiran konsumen, merek, produk, serta layanan yang diberikan juga sangat penting bagi perkembangan restoran saat ini terutama yang mempengaruhi konsumen adalah dengan adanya informasi yang disebarkan di dalam content social media ataupun pengunaan iklan yang terdapat dalam restoran tersebut. Tujuan penelitian untuk mengembangkan model konseptual consumer engagement melalui konten media sosial dan iklan. Teknik pengambilan sampel menggunakan kuesioner secara daring dengan teknik non probability sampling. Sampel dalam penelitian yang valid sebanyak 120 responden. Metode analisis data menggunakan PLS-SEM. Hasil penelitian membuktikan bahwa semakin tinggi penggunaan iklan dalam promosi maka semakin tinggi tingkat consumer engagement, begitu juga semakin tinggi penggunaan konten media sosial maka semakin tinggi tingkat consumer engagement yang dapat disimpulkan seluruh hipotesis didukung. Penelitian ini memberikan wawasan kepada manajer pemasar restoran mengenai cara memanfaatkan konten media sosial dan iklan media sosial dalam meningkatkan consumer engagement.
\end{abstract}

Keyword : Content Social Media, Iklan, Consumer Engagement

\section{Consequences Consumer Engagement : Advertisement and Content Social Media Focusing on Restaurant Indonesia Consumers A Perspective Uses and Gratification Theory}

\section{Abstract}

During the COVID-19 pandemic, social media also builds the influence of advertisements and content to influence consumers of favourite restaurants in Indonesia in purchasing products and services and will build consumer engagement. Thus, the marketing carried out by the restaurant at this time also has a major impact on the sustainability of the restaurant to attract existing consumers to create stability in the restaurant, and there is a long-term period for the restaurant to expand or promote its development. The presence of consumers, brands, products, and services provided is also significant for the development of restaurants today, especially those that affect consumers are the information disseminated in social media content or the use of advertisements contained in the restaurant. The research objective is to develop a conceptual model of consumer engagement through social media content and publicity-the sampling technique used online questionnaires with non-probability sampling techniques. The sample in the valid study was 120 respondents-data analysis method using PLS-SEM. The study results prove that the higher the use of advertising in promotions, the higher the level of consumer engagement, as well as the higher the use of social media content, the higher the level of consumer engagement, which can be concluded that all hypotheses are supported. This research provides insight to restaurant marketers on utilizing social media content and social media advertising to increase consumer engagement.

Keywords: Social Media Content, Advertising, Consumer Engagement 


\section{PENDAHULUAN}

Pada lingkungan pemasaran mengenai layanan yang juga berubah dengan cepat, hubungan merek dengan konsumen merupakan salah satu hal yang paling penting, terutama dalam meraih kinerja hubungan antar merek dan konsumen yang harus tetap stabil serta memiliki waktu dengan jangka panjang. Adanya hal tersebut juga harus didasarkan pada pemahaman yang mendalam mengenai konsumen, karena pengalaman yang dimiliki oleh konsumen merupakan salah satu variabel penting dalam pemasaran modern, sehingga keterlibatan pada konsumen juga telah menjadi masalah bagi perusahaan. Hubungan yang dibangun antara konsumen dengan merek juga mewakili sebagai salah satu motivasi serta keadaan logis yang dimiliki atau dihasilkan dari interaksi secara intensif terutama dari adanya pengalaman yang dijalin antara konsumen dengan objek yang dimiliki dalam perusahaan tersebut (misalnya dalam produk yang dimiliki oleh perusahaan, ataupun toko yang dimiliki oleh perusahaan) (Brodie et al., 2011). Artinya untuk mendorong, pemasaran dalam industri makanan tersebut juga harus fokus membangun hubungan antara konsumen dan merek dari perspektif pengalaman konsumen (Sashi, 2012). Dalam industri makanan, hubungan yang dibangun secara intim dan juga secara jangka panjang tersebut juga telah terjalin dengan konsumen, dan pelanggan juga akan mengandalkan informasi yang dihasilkan oleh aktivitas saat dirinya berbelanja. Sehingga, dalam hal ini industri makanan atau restoran juga memerlukan adanya pengalaman secara interaktif antar konsumen baik itu kepercayaan yang diberikan kepada restoran ataupun loyalitas yang dimiliki dalam kepentingan sektor restoran. Hal ini juga didukung oleh pendapat yang disampaikan oleh Oliver (1999) dimana, dirinya juga menyatakan bahwa konsumen juga membutuhkan informasi pada proses pertama dalam membentuk keyakinan, sehingga restoran dapat membentuk keyakinan sebagai salah satu dasar untuk sikap yang akan menciptakan perilaku serta keputusan pada konsumen (Oliver,1999). Restoran tersebut juga dapat melibatkan konsumen secara aktif dalam menentukan berbagai sikap yang disukai terhadap produk tertentu. Seiring dengan perkembangannya loyalitas serta respon yang diberikan oleh konsumen terhadap restoran tersebut juga memiliki pengaruh yang besar terhadap perkembangan media sosial atau biasanya disebut dengan internet. Perkembangan suatu restoran juga akan dipengaruhi oleh internet, terutama dari informasi yang disajikan kepada konsumen yang membuat ketertarikan serta minat yang timbul dari konsumen untuk menjadikan salah satu restoran sebagai tempat favorit dirinya sendiri. Perkembangan jejaring sosial media termasuk internet dan juga Facebook, Twitter, Instagram, atau Whatsapp tersebut juga memiliki pengaruh yang kuat kepada konsumen jika dibandingkan dengan adanya bauran promosi tradisional (Muntinga et al., 2011). Dalam data yang diberikan oleh APJII (Asosiasi Penyelenggara Jasa Internet Indonesia) dapat dilihat sebagai berikut:

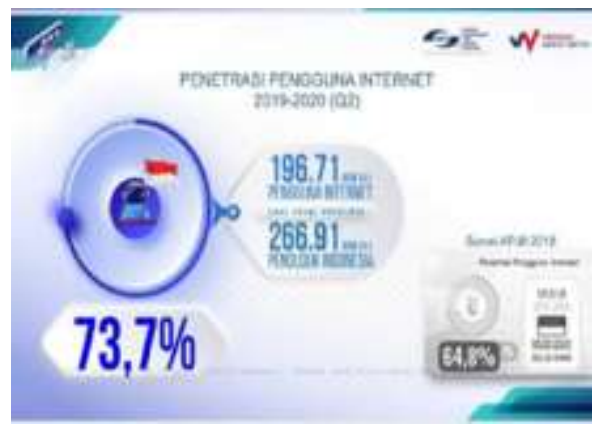

Sumber : APJII (Asosiasi Penyelenggara Jasa Internet Indonesia) 2020

Gambar 1. Penetrasi Pengguna Internet di Negara Indonesia

Dari data yang diberikan oleh APJII (Asosiasi Penyelenggara Jasa Internet Indonesia) tersebut membuktikan bahwa populasi penduduk yang berada di negara Indonesia sejak tahun 2019 hingga tahun 2020 terdapat 266,91 juta penduduk dengan pengguna internet hampir setengah dari penduduk Indonesia tersebut, dimana pengguna internet negara Indonesia sebesar 196,71 juta penduduk yang aktif dalam menggunakan internet. Hal tersebut menunjukan bahwa pengguna internet di negara Indonesia mencapai $73,7 \%$ dari jumlah populasi penduduk di negara Indonesia. Dari data yang diberikan tersebut juga menyatakan bahwa adanya peluang serta efektivitas terhadap penggunaan internet untuk hal bauran promosi juga sangat mempengaruhi dalam pemasaran, karena lebih dari setengah penduduk di negara Indonesia juga sudah menggunakan internet sebagai salah satu kebutuhan sehari-harinya, baik itu memenuhi informasi yang dibutuhkan ataupun mencari mengenai informasi yang dibutuhkan untuk memenuhi kebutuhan hiburan serta kebutuhan dalam pekerjaan. Dapat dinyatakan juga, bahwa kehidupan masyarakat di negara Indonesia juga tidak dapat lepas dari keberadaan internet, karena masyarakat di negara Indonesia juga sangat memperlukannya. Dalam sumber yang 
selanjutnya, masih sama disampaikan oleh APJII (Asosiasi Penyelenggara Jasa Internet Indonesia) tersebut, dari pertanyaan yang telah diberikan kepada koresponden mengenai alasan mengapa seseorang menggunakan internet dalam kesehariannya tersebut, bahwa dapat diperoleh paling utama alasan utama individu di negara Indonesia menggunakan internet adalah untuk menggunakan sosial media di dalam kesehariannya tersebut. Seperti yang sudah disampaikan sebelumnya, bahwa pengunaan media sosial tersebut untuk memperoleh informasi yang dibutuhkan atau informasi yang ingin diperoleh dalam kehidupan sehari-hari. Untuk memasarkan informasi untuk seluruh industri tentunya dinilai sangat strategis, karena pengguna media sosial di negara Indonesia semakin tahun juga mengalami peningkatan dan setengah dari populasi di negara Indonesia juga menggunakan internet di dalam kehidupan sehari-harinya, baik itu diperuntukan untuk melakukan komunikasi jarak jauh ataupun memperoleh informasi. Data lain juga menunjukkan pada gambar kedua mengenai penjualan dan juga peningkatan pelayanan restoran di negara Indonesia dari tahun 2013 hingga tahun 2014

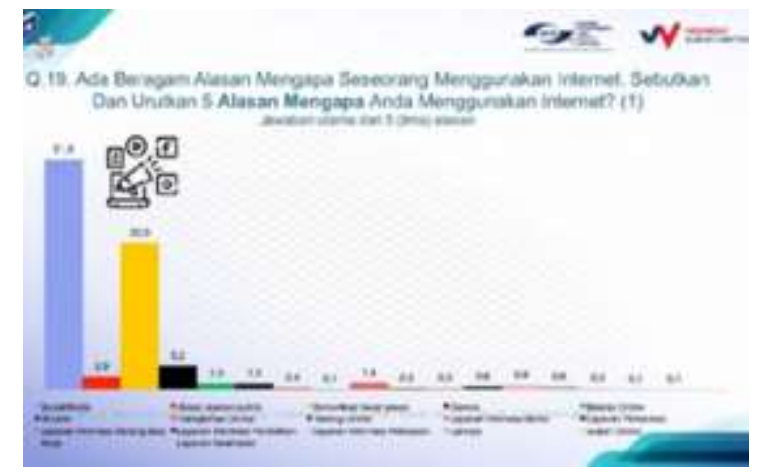

Sumber : APJII (Asosiasi Penyelenggara Jasa Internet Indonesia) 2020

Gambar 2. Data Pertanyaan Alasan

Seseorang Menggunakan Internet

Promosi produk di media sosial terutama tercermin melalui pesan pemasaran dan keterlibatan konsumen. Penelitian sebelumnya berfokus pada hubungan antar keterlibatan konsumen dan kinerja ekonomi di media sosial.(Chen and Lin, 2019; Oh et al.,2015; Wang et al., 2019) Studi pemasaran ini, sementara berfokus pada desain pesan pemasaran (Yadav and Pavlou, 2014). Oleh sebab itu penelitian ini bertujuan untuk menjawab pertanyaan penelitian sebagai berikut Dengan menggunakan uses gratification theory bagaimana proses yang melibatkan advertisement dapat memengaruhi consumer engagement?, dengan menggunakan uses gratification theory bagaimana proses yang melibatkan content social media dapat memengaruhi customer engagement? Tujuan penelitian untuk mengembangkan model konseptual consumer engagement melalui konten media sosial dan iklan.

\section{KAJIAN PUSTAKA}

Penerapan uses and gratifications Theory (UGT) (Katz and Foulkes, 1962) dan prinsip yang mendasari teori persuasi seperti teori pemrosesan ganda (Kahneman, 2011) studi ini menawarkan penjelasan tentang bagaimana jenis yang spesifik dari konten media sosial (dikelompokkan dalam daya tarik pesan rasional versus pesan emosional) dapat memengaruhi aktif dan pasif perilaku keterlibatan konsumen online. Penggunaan awal teori ini difokuskan paad penggunaan media tradisional seperti televisi dan radio (Harwood, 1999). Seiring perkembangan teknologi sudah dialihkan focus ke media baru yakni media sosial dan menerapkan teori ini untuk memahami media sosial dan aktivitas pengguna (Cheung et al., 2011; Whiting and Williams, 2013).Teori ini mengasumsikan bahwa pengguna media adalah penonton yang berorientasi pada tujuan, aktif dan cerdas (Chen, 2011; Leiner et al., 2018; Whiting and Williams, 2013)

\section{Social Media dan Consumer Engagement}

Munculnya saluran media baru dan juga meningkatnya terhadap popularitas internet juga mencerminkan perkembangan teknologi Web 2.0 serta juga memungkinkan pelanggan untuk dapat melakukan interaksi secara langsung dengan mudah dan juga terhubung dengan pelanggan serta perusahaan melalui kehadiran media sosial (Rahmawati \& Aji, 2015). Interaksi yang dibangun tersebut juga telah dipicu oleh hubungan yang dibangun oleh konsumen serta perusahaan, sehingga perwujudan konsumen yang dibentuk dari pengalaman hubungan interaktif tersebut juga biasanya disebut sebagai Consumer Engagement (Verhoef et al., 2010). Seiring dengan berkembangnya juga, adanya Consumer Engagement tersebut juga menggunakan Customer Relationship Management atau biasanya disebut dengan CRM yang secara langsung membutuhkan adanya perspektif baru sebagai salah satu pengembangan. Munculnya platform media sosial mengendapkan pergeseran paradigma pelanggan online mengubah cara pelanggan berinteraksi satu sama lain dan dengan merek. 
Secara khusus interaktif media sosial telah mengubah konsumen dari pengamat konten pasif menjadi pengamat konten aktif yang benar-benar membuat konten dalam jumlah besar melalui interaksi online, perilaku konsumen (Malthouse et al., 2013). Pergeseran ini merupakan konsep keterlibatan pelanggan yang mengakui bahwa pelanggan memang terlibat dalam interaksi ini (Bijmolt et al., 2010). Social media memengaruhi tingkat pelanggan yang terlibat dengan organisasi, dan tingkat keterlibatan pelanggan yang baik dipengaruhi oleh pendekatan organisasi terhadap manejemen hubungan pelanggan (Malthouse et al., 2013). Penelitian ini membutuhkan perspektif perilaku keterlibatan (Gummerus et al., 2012) di dalam lingkungan platform media sosial dan memberikan wawasan yang lebih luas mengenai perilaku manifestasi keterlibatan melalui media sosial. Consumer interaction adalah keterlibatan pelanggan dengan perusahaan yang berkelanjutan dengan tujuan memperkuat nilai brand dalam kehidupan pelanggan melalui percakapan, pengalaman, dan komunitas online pada halaman media sosial perusahaan (Hollebeek, et al., 2014).

Customer engagement ditandai dengan adanya interaksi berulang antara pelanggan dan perusahaan yang secara tidak langsung dapat memperkuat investasi emosional, psikologis, dan fisik yang dimiliki pelanggan terhadap perusahaan (Palazon et al., 2015).

Berdasarkan penjelasan di atas sehingga dapat dibuat hipotesis sebagai berikut :

$\mathrm{H} 1$ : semakin tinggi penggunaan konten media sosial maka semakin tinggi tingkat consumer engagement

\section{Iklan dan Consumer engagement}

Menurut Brodie et al (2013), consumer engagement merupakan proses yang tidak terstruktur secara teratur, melainkan sebuah fase yang sekuensial sepanjang waktu. Model ini menggambarkan hubungan yang muncul diantara aspek kognitif, emosional dan perilaku dari consumer engagement serta objek spesifiknya yang mencirikan tingkat kompleksitas dari pelanggan. Studi (Prayitno et al., 2020) menyatakan media sosial menjadi sarana konsumen untuk menyalurkan pendapat, serta berperan dalam proses pembentukan suatu merek. sosial media digunakan dalam membentuk customer engagement yang pada dasarnya bertujuan untuk melibatkan konsumen secara lebih interaktif, karena dengan adanya hubungan interaktif di dalam media sosial inilah yang mampu memperluas hubungan relasional dengan customer dan mengubah cara pandang hubungan daripada di dalam media trasional yang biasanya komunikasinya bersifat satu arah. Engagement online adalah konsep yang berkembang dan penting untuk periklanan dan ahli strategi media(Peacock et al., 2011)

Iklan yang menimbulkan emosi konsumen dapat menyebabkan reaksi bawah sadar yang menggantikan tanggapan logis dan pragmatis konsumen untuk menciptakan ikatan yang tidak terpisahkan dengan suatu merek. Daya tarik emosional positif seperti kepuasan, kebahagiaan dan cinta memiliki pengaruh positif pada keterlibatan konsumen. Di sisi lain, daya tarik emosional negatif berhubungan negatif dengan keterlibatan konsumen.(Kujur \& Singh, 2018). Studi dari menemukan bahwa konten persuasive inklusif - seperti konten emosional dan filantropis meningkatkan keterlibatan dengan pesan. konten informatif - seperti harga, ketersediaan, dan fitur produk - mengurangi keterlibatan saat disertakan dalam pesan secara terpisah, tetapi tingkatkan keterlibatan jika diberikan dalam kombinasi dengan atribut persuasif. Konten persuasif tampaknya menjadi kunci keterlibatan yang efektif dan menginformasikan desain periklanan di media sosial, dan metodologi yang dikembangkan menjadi kode konten dalam skala besar data tekstual memberikan rerangka kerja untuk studi masa depan tentang tata bahasa alami yang tidak terstruktur seperti konten iklan atau ulasan produk (Lee et al., 2014). Keterlibatan konsumen mengacu pada perilaku konsumen yang berfokus pada perusahaan atau merek tertentu yang melampaui motif pembelian (Doorn et al., 2010)). Penelitian sebelumnya telah diklasifikasikan keterlibatan konsumen online sebagai sosial atau konvensional. Keterlibatan sosial meliputi media sosial seperti Instagram, facebook. Sementara keterlibatan konvensional meliputi situs web restoran (Gomez et al., 2015). Keterlibatan konsumen di media sosial melibatkan konten antara satu konsumen dengan konsumen lainnya (Heinonen, 2011) Oleh sebab itu keterlibatan konsumen di media sosial menciptakan lingkungan untuk menerima dan menukar informasi (Kaplan, 2012). Penelitian sebelumnya juga telah meneliti pengaruh keterlibatan media sosial pada hasil bisnis dan kesadaran pengguna (Kou et al., 2019; Schindler and Bickart, 2012).

Berdasarkan penjelasan di atas sehingga dapat dibuat hipotesis sebagai berikut : 
$\mathrm{H} 2$ : semakin tinggi penggunaan konten iklan maka semakin tinggi tingkat consumer engagement

\section{METODE PENELITIAN}

Metode penelitian yang digunakan
metode penelitian kuantitatif. Teknik pengambilan data menggunakan kuesioner online merupakan data primer, tinjauan literatur yang merupakan data sekunder. Teknik analisis data menggunakan PLS-SEM. Populasi dalam penelitian ini merupakan konsumen restoran favourite Indonesia. Menurut (Roscoe, 1975; Sekaran \& Bougie, 2016) ukuran sampel untuk analisis multivariat harus berkali-kali (sebaiknya sepuluh kali atau lebih) jumlah variabel yang diuji. Dalam penelitian ini ada 16 pertanyaan sehingga diharapkan sampel minimal 160 responden. Penulis mendapatkan 120 responden yang dapat diolah datanya dan dinyatakan valid dan reliable. Teknik pengambilan sample menggunakan non probability sampling. Karena estimasi model berbasis PLS-SEM selalu bergantung pada reliabilitas komposit, terlepas dari spesifikasi model pengukurannya (Sarstedt et al., 2017). Studi simulasi yang dilakukan oleh Sarstedt et al. (2016) juga menunjukkan bahwa PLS-SEM merupakan pilihan yang lebih tepat untuk mengestimasi data model komposit. Menggunakan komposit sebagai input, PLS-SEM menerapkan serangkaian regresi untuk memaksimalkan varian yang dijelaskan dari konstruksi endogen (Sarstedt et al., 2017). Ini adalah teknik yang disukai jika studi menggali model prediksi (Hair, Hult, Ringle, Sarstedt dan Thiele, 2017; Rigdon et al., 2017).

\section{HASIL DAN PEMBAHASAN}

Dalam melakukan penyebaran terhadap kuesioner yang telah diisi oleh koresponden tersebut, peneliti juga telah memperoleh jumlah koresponden wanita sebesar 42 dan jumlah pria sebesar 79 orang dengan memiliki rata-rata umur 17 hingga 25 tahun pada tingkat SMA/SMK atau sederajatnya, sehingga pekerjaan rata-rata pada koresponden tersebut merupakan pelajar atau mahasiswa yang sedang mengikuti pembelajaran akademik dengan rata-rata pendapatan perbulannya dibawah 3.000 .000 rupiah dalam melihat pengaruhnya terhadap restoran favoritnya tersebut. Target utama dalam melakukan penelitian ini juga terlihat dapat terpenuhi dengan baik, karena rata-rata pengguna yang menggunakan media sosial ataupun internet secara intens dalam kehidupan sehari-harinya merupakan remaja atau yang berumur hingga 25 tahun, sehingga dalam memperoleh segala jenis informasi juga menggunakan internet dan juga media sosial.

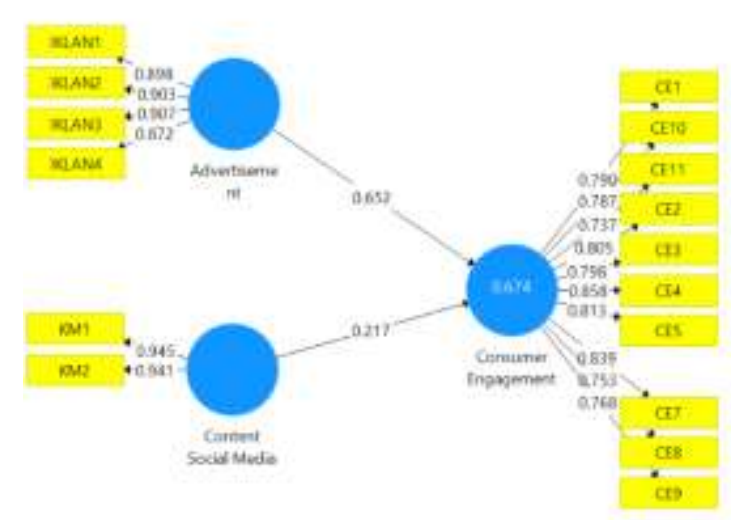

Sumber : Hasil olahan data (2021)

Gambar 3. Output Loading Factor

Evaluasi model pengukuran dibagi menjadi tiga tahap yaitu uji validitas konvergen, uji validitas diskriminan, dan uji reliabilitas komposit. Korelasi antara skor indikator dan skor konstruk dapat menguji validitas indikator reflektif. Pengukuran indikator reflektif menunjukkan perubahan suatu indikator dalam suatu konstruk ketika indikator lain dalam konstruk yang tepat berubah. Berikut adalah hasil perhitungan yang dilakukan dengan smart PLS 3.0

Menurut Ghozali \& Latan (2015) suatu korelasi dapat dikatakan memenuhi validitas konvergen jika memiliki nilai loading lebih besar dari 0,5. Outputnya menunjukkan bahwa faktor pembebanan memberikan nilai di atas nilai yang disarankan 0,5 . sehingga indikator yang digunakan dalam penelitian ini telah memenuhi validitas konvergen

\section{Uji Reliabilitas dan Validitas Konvergen}

Menurut (Hair et al., 2019) variabel laten dapat memiliki reliabilitas yang baik jika nilai reliabilitas komposit lebih besar dari 0,7 . Nilai Cronbach alpha lebih signifikan dari 0,7. Nilai AVE $\geq 0,5$, menurut Hair et al. (2019), menyatakan bahwa setiap konstruk memenuhi persyaratan validitas konvergen.

Semua variabel laten yang diukur dalam penelitian ini memiliki nilai Cronbach's alpha dan composite reliability yang lebih besar dari 0,7 sehingga dapat dikatakan semua variabel laten reliabel. Semua konstruk memenuhi syarat validitas konvergen dan menunjukkan bahwa akar kuadrat masing- 
masing variabel AVE lebih besar dari nilai korelasi antar variabel. Hasilnya, dapat disimpulkan bahwa penelitian ini memenuhi persyaratan uji validitas diskriminan.

Tabel 1. Uji reliabilitas dan Validitas

\begin{tabular}{llll}
\hline construct & $\begin{array}{l}\text { Cronbach' } \\
\text { s alpha }\end{array}$ & $\begin{array}{l}\text { Composit } \\
\text { e } \\
\text { reliability }\end{array}$ & $\begin{array}{l}\text { Average } \\
\text { variance } \\
\text { extracte } \\
\text { d (AVE) }\end{array}$ \\
\hline $\begin{array}{l}\text { Advertisemen } \\
\mathrm{t}\end{array}$ & 0.918 & 0.942 & 0.902 \\
$\begin{array}{l}\text { Consumer } \\
\begin{array}{l}\text { Engagement } \\
\text { Content } \\
\text { Social Media }\end{array}\end{array}$ & 0.935 & 0.945 & 0.633 \\
\multicolumn{3}{c}{ Sumber : Olahan Data PLS-SEM (2021) }
\end{tabular}

\section{Kriteria Fornell \& Larcker dan HTMT Ratio}

Validitas diskriminan dapat dinilai dengan menggunakan indikator cross-loading, kriteria Fornell dan Larcker, dan rasio korelasi Heterotrait-monotrait (HTMT). Dilihat dari cross loadingnya, indikator factor loading pada konstruk yang ditugaskan harus lebih besar dari semua pembebanan pada konstruk lain, dengan syarat nilai cut off factor loading lebih signifikan dari 0,70. (Hair et al., 2011; Hair et al., 2014). Jika HTMT> 0,90 untuk konstruksi yang serupa secara konseptual menunjukkan masalah validitas diskriminan (Henseler et al., 2015). Kriteria Fornell-Larcker digunakan untuk menilai validitas diskriminan. Menurut Hair et al. (2014), kriteria Fornell-Lacker membandingkan nilai akar kuadrat AVE dengan korelasi antar variabel. Jika nilai akar kuadrat AVE untuk setiap variabel lebih besar dari nilai korelasi antar variabel dalam model, validitas diskriminan terpenuhi.

Tabel 2. HTMT Ratio dan Fornell Larcker Criterion

\begin{tabular}{llll}
\hline construct & $\begin{array}{l}\text { Advertiseme } \\
\mathrm{nt}\end{array}$ & $\begin{array}{l}\text { Consumer } \\
\text { Engageme } \\
\mathrm{nt}\end{array}$ & $\begin{array}{l}\text { Conte } \\
\mathrm{nt} \\
\text { Social } \\
\text { Media }\end{array}$ \\
\hline $\begin{array}{l}\text { Consumer } \\
\begin{array}{l}\text { Engagement } \\
\text { Content }\end{array}\end{array}$ & 0.868 & & \\
$\begin{array}{l}\text { Social } \\
\text { Media }\end{array}$ & 0.797 & 0.751 & \\
\hline
\end{tabular}

\begin{tabular}{llll}
\hline \multicolumn{5}{l}{ Fornell-Larcker Criterion } & & \\
\hline $\begin{array}{l}\text { Advertiseme } \\
\text { nt }\end{array}$ & 0.896 & & \\
\hline $\begin{array}{l}\text { Consumer } \\
\text { Engagement }\end{array}$ & 0.807 & 0.796 & \\
\hline $\begin{array}{l}\text { Content } \\
\text { Social }\end{array}$ & 0.714 & 0.682 & 0.943 \\
Media & & & \\
\hline
\end{tabular}

Sumber : Olahan Data PLS-SEM (2021)

Evaluasi Model Struktural (Inner Model)
Evaluasi model struktural di S.E.M. dengan P.L.S. dilakukan dengan melakukan uji RSquared $\left(R^{2}\right)$ dan uji signifikansi melalui estimasi koefisien jalur.

Menurut (Hair et al., 2019), kriteria Multikolinearitas> 10: Kritis, 5-10: kemungkinan, 3-5: disarankan, $<3$ : ideal

Tabel 3. Variance Inflation Factor

\begin{tabular}{llll}
\hline construct & $\begin{array}{l}\text { Advertiseme } \\
\mathrm{nt}\end{array}$ & $\begin{array}{l}\text { Consumer } \\
\text { Engageme } \\
\mathrm{nt}\end{array}$ & $\begin{array}{l}\text { Conte } \\
\mathrm{nt} \\
\text { Social } \\
\text { Media }\end{array}$ \\
\hline Advertiseme & & 2.039 &
\end{tabular}

nt

Consumer

Engagement

Content

Social

Media

Sumber : Olahan Data PLS-SEM (2021)

Hasil menunjukkan bahwa tidak ada masalah multikolinearitas, dan variabel bebas tidak berkorelasi

\section{R Squared $\left(\mathbf{R}^{2}\right) \quad$ Menguji Koefisien}

Determinasi

Output untuk nilai $\mathrm{R}^{2}$ dengan menggunakan program komputer smart PLS 3.0 diperoleh

\begin{tabular}{lll}
\multicolumn{3}{l}{ Tabel 4. Pengujian R squared } \\
\hline construct & $\begin{array}{l}\mathrm{R} \\
\text { Square }\end{array}$ & $\begin{array}{l}\mathrm{R} \\
\text { Square } \\
\text { adjusted }\end{array}$ \\
\hline $\begin{array}{l}\text { Consumer } \\
\text { engagement }\end{array}$ & 0.674 & 0.668 \\
\hline mber : Olahan Data PLS-SEM (2021)
\end{tabular}

Nilai R-Squared $\left(\mathrm{R}^{2}\right)$ digunakan untuk mengukur seberapa besar pengaruh variabel laten independen tertentu terhadap variabel dependen laten. Menurut (Hair et al., 2014) jika nilai $R^{2}>0.75$ dikatakan substansial jika nilai $R^{2}$ sebesar $0.5-0.75$ berarti sedang; jika nilai $R^{2}<0,5$ dikatakan lemah. Hasil $R^{2}$ untuk consumer engagement adalah 0,674 . Hal ini menunjukkan bahwa model tersebut tergolong sedang.

\section{Uji Signifikansi}

Uji signifikansi dengan PLS-SEM bertujuan untuk menganalisis pengaruh advertisement dan content social media sebagai variabel independen terhadap variabel dependen consumer engagement. Pengujian hipotesis dengan metode PLS-SEM dilakukan dengan melakukan proses bootstrap dengan bantuan program komputer smart PLS 3.0 sehingga diperoleh hubungan antara pengaruh variabel eksogen terhadap variabel endogen sebagai berikut 
Tabel 5. Pengujian Q squared predict

\begin{tabular}{ll}
\hline construct & $\begin{array}{l}\mathrm{Q} \\
\end{array}$ \\
& $\begin{array}{l}\text { Square } \\
\text { predict }\end{array}$ \\
\hline Consumer & 0.668 \\
engagement &
\end{tabular}

Sumber : Olahan Data PLS-SEM (2021)

Menurut Hair et al. (2019) $\mathrm{Q}^{2}$ Prediksi> 0 0,25: prediksi kecil, 0,25 - 0,50: prediksi sedang, 0,50: prediksi besar. Model penelitian memiliki nilai prediksi yang besar karena memiliki nilai prediksi $\mathrm{Q}^{2}$ adalah 0,668 yang dapat memprediksi model consumer engagement. Menurut Hair et al. (2019), signifikansi adalah T statistik> T Tabel 1,645

\begin{tabular}{llll}
\multicolumn{4}{c}{ Tabel 6 . Pengujian Hipotesis } \\
\hline Hipotesis & $\begin{array}{l}\text { Standardiz } \\
\text { ed } \\
\text { coefficient }\end{array}$ & $\begin{array}{l}\text { T } \\
\text { statist }\end{array}$ & $\begin{array}{l}\text { ic } \\
\text { valu } \\
\text { es }\end{array}$ \\
\hline $\begin{array}{l}\text { Advertisement } \rightarrow \text { cons } \\
\text { umer engagement }\end{array}$ & 0.073 & 8.963 & 0.00 \\
$\begin{array}{l}\text { Content Social } \\
\text { Media } \rightarrow \text { consumer }\end{array}$ & 0.077 & 2.812 & 0 \\
engagement & & & 5 \\
\hline
\end{tabular}

Sumber : Olahan Data PLS-SEM (2021)

T Statistik > signifikansi T Tabel adalah 1.645. Penelitian menunjukkan bahwa Hipotesis 1 adverstisement berpengaruh terhadap consumer engagement yang berarti hipotesis didukung dan hipotesis 2 content social media berpengaruh terhadap consumer engagement yang berarti hipotesis juga didukung.

\section{PENUTUP}

Dari pembahasan diatas dapat dibuat simpulan penelitian ini bahwa hipotesis pertama dan kedua didukung atau hipotesis tidak ditolak. Manajer pemasaran juga harus memberikan informasi lebih banyak kepada pelanggan restoran. Menyampaikan informasi mengenai produk restoran berkualitas tinggi, makanan yang enak di media sosial dan iklan merupakan cara yang penting dan efektif untuk meningkatkan consumer engagement dan dapat meningkatkan kinerja penjualan. Seperti penelitian lainnya, penelitian ini bukannya tanpa keterbatasan. Studi ini berfokus pada konten iklan dan konten sosial media untuk membangun consumer engagement. Terdapat jenis komunikasi pemasaran lainnya yang termasuk pemasaran interaktif meliputi promosi dari mulut ke mulut, pemasaran langsung, dan ulasan konsumen yang diposting di berbagai platform media sosial baik oleh restoran atau konsumen. Studi di masa depan diharapkan dapat menentukan peran jenis komunikasi pemasaran lainnya dalam mengembangakan dan meningkatkan brand dan consumer engagement. Karena menggunakan pendekatan survey cross sectional temuan penelitian ini didasarkan pada data utama. Peneliti selanjutnya disarankan untuk meneliti hubungan antara variabel menggunakan variabel lainnya seperti social interactive, brand credibility, buying online.

\section{DAFTAR PUSTAKA}

Bijmolt, T.H., Leeflang, P.S., Block, F., Eisenbeiss, M., Hardie, B.G., Lemmens, A. and Saffert, P. (2010). Analytics for customer engagement", Journal of Service Research, Vol. 13 No. 3, pp. 341 356.

Brodie, R. J., Hollebeek, L. D., Jurić, B., \& Ilić, A. (2011). Customer engagement: Conceptual domain, fundamental propositions, and implications for research. Journal of Service Research. https://doi.org/10.1177/10946705114117 03

Brodie, R. J., llic, A., Juric, B., \& Hollebeek, L. (2013). Consumer engagement in a virtual brand community: An exploratory analysis. Journal of Business Research, 66(1), 105-114. https://doi.org/10.1016/j.jbusres.2011.07. 029

Chen, S. and Lin, C. (2019). Understanding the effect of social media marketing activities: the mediation of social identification, perceived value, and satisfaction", Technological Forecasting and Social Change, Vol. 140, pp. 22-32.

Chen, G. M. (2011). Tweet this: a uses and gratifications perspective on how active Twitter use gratifies a need to connect with others", Computers in Human Behavior, Vol. 27 No. 2, pp. 755-762.

Cheung, C.M.K., Chiu, P.-Y. and Lee, M. K. O. (2011). Online social networks: why do students use Facebook?", Computers in Human Behavior, Vol. 27 No. 4, pp. 1337-1343.

Doorn, J.V., Lemon, K.N., Mittal, V., Nass, S., Pick, D., Pirner, P. and Verhoef, P. C. (2010). Customer engagement behavior: theoretical foundations and research directions", Journal of Service Research, Vol. 13 No. 3, pp. 253-266.

Gomez, J.B., Amado, J.B. and Montes, F. L. (2015). Impact of IT infrastructure on customer service performance: the role of 
micro-IT capabilities and online customer engagement", Proceedings of the 19th Pacific Asia Conference on Information Systems, Singapore, pp. 1-16.

Gummerus, J., Liljander, V., Weman, E. and Pihlström, M. (2012). Customer engagement in a Facebook brand community", Management Research Review, Vol. 35 No. 9, pp. 857-877.

Harwood, J. (1999). Age identification, social identity gratifications, and television viewing", Journal of Broadcasting and Electronic Media, Vol. 43 No. 1, pp. 123136.

Heinonen, K. (2011). Consumer activity in social media: managerial approaches to consumers' social media behavior", Journal of Consumer Behavior, Vol. 10 No. 6, pp. 356-364.

Hollebeek, L. D., Glynn, M. S., dan Brodie, R. J. (2014). Consumer Brand Engagement in Social Media: Conceptualization, Scale Development and Validation. Journal of Interactive Marketing, 28(2), 149-165.

Kahneman, D. (2011). Thinking, Fast and Slow, Macmillan, New York, NY.

Kaplan, A. (2012). If you love something, let it go mobile: mobile marketing and mobile social media 434", Business Horizons, Vol. 55 No. 2, pp. 129-139.

Katz, E. and Foulkes, D. (1962). On the use of the mass media as 'escape': clarification of a concept", The Public Opinion Quarterly, Vol. 26, pp. 277-388.

Kou, G., Chao, X., Peng, Y. and Alsaadi, F. E. (2019). Machine learning methods combined with financial systemic risk", Technological and Economic Development of Economy, Vol. 25 No. 5 , pp. 716-742.

Kujur, F., \& Singh, S. (2018). Emotions as predictor for consumer engagement in YouTube advertisement. Journal of Advances in Management Research, 15. https://doi.org/10.1108/JAMR-05-20170065

Lee, D., Hosanagar, K., \& Nair, H. (2014). The Effect of Advertising Content on Consumer Engagement: Evidence from Facebook. The Wharton School, August, 1-42.

http://www.researchgate.net/publication/2 57409065_The_Effect_of_Advertising_C ontent_on_Consumer_Engagement_Evid ence_from_Facebook_*/file/72e7e52533 d668b60b.p df

Leiner, D.J., Kobilke, L., Rueß, C. and Brosius, H.-B. (2018). Functional domains of social media platforms: structuring the uses of Facebook to better understand its gratifications", Computers in Human Behavior, Vol. 83, pp. 194-203.

Malthouse, E.C., Haenlein, M., Skiera, B., Wege, E. and Zhang, M. (2013). Managing customer relationships in the social media era: introducing the social CRM house", Journal of Interactive Marketing, Vol. 27 No. 4, pp. 270-280.

Muntinga, D. G., Moorman, M., \& Smit, E. G. (2011). Introducing COBRAs: Exploring motivations for Brand-Related social media use. International Journal of Advertising. https://doi.org/10.2501//JA30-1-013-046

Oh, O., Eom, C.Y. and Rao, H. R. (2015). Role of social media in social change: an analysis of collective sense-making during the 2011 Egypt revolution", Information Systems Research, Vol. 26 No. 1, pp. 210-223.

Oliver R.L. (1999). Whence customer loyalty. Journal of Marketing.

Palazon, M., Sicilia, M., dan Lopez, M. (2015). The Influence of 'Facebook Friends' on The Intention to Join Brand Pages. Journal of Product and Brand Management, 24(6), 580-595.

Peacock, J., Purvis, S. dan Hazlett, R. L. (2011). Which broadcast medium better drives engagement?: measuring the powers of radio and television with electromyography and skin-conductance measurements. Journal of Advertising Research 51(4): 578-585.

Prayitno, A., Putriani, A., Wibowo, A., \& ... (2020). PENGARUH SOSIAL MEDIA MARKETING. CUSTOMER ENGAGEMENT DAN DIGITAL ADVERTISING TERHADAP KEPERCAYAAN MERK (Pengguna GOJEK .... Jurnal Manajemen ..., 33(2), 123-130.

https://ejournal.stieibbi.ac.id/index.php/jm b/article/view/161

Rahmawati, E., \& Aji, S. (2015). Pengaruh Customer Engagement Terhadap Kepuasan Pelanggan Dan Kepercayaan Merek Serta Dampaknya Pada Loyalitas Merek. Jurnal Riset Ekonomi Dan Manajemen.

https://doi.org/10.17970/jrem.15.150204.i d

Roscoe, J. T. (1975). Fundamental Research Statistics for the behavioral Sciences, 2nd edition, New York: Holt, Rinehart and Winston.

Sashi, C. M. (2012). Customer engagement, buyer-seller relationships, and social 
media. Management Decision. https://doi.org/10.1108/00251741211203 551

Schindler, R.M. and Bickart, B. (2012). Perceived helpfulness of online consumer reviews: the role of message content and style", Journal of Consumer Behavior, Vol. 11 No. 3, pp. 234-243.

Sekaran, U., \& Bougie, R. (2016). Research Methods For Business: A Skill-Building Approach. Wiley.

Verhoef, P. C., Reinartz, W. J., \& Krafft, M. (2010). Customer engagement as a new perspective in customer management. Journal of Service Research. https://doi.org/10.1177/10946705103754 61
Wang, W., Chen, R., Ou, C. and Ren, S. (2019). Media or message, which is the king in social commerce? An empirical study of participants' intention to repost marketing messages on social media", Computers in Human Behavior, Vol. 93, pp. 176-191.

Whiting, A. and Williams, D. (2013). Why people use social media: a uses and gratifications approach", Qualitative Market Research: An International Journal, Vol. 16 No. 4, pp. 362-369.

Yadav, M.S. and Pavlou, P. A. (2014). Marketing in computer-mediated environments: research synthesis and new directions", Journal of Marketing, Vol. 78, pp. 20-40. 